\title{
Iridium-catalyzed asymmetric ring-opening reactions of oxabicyclic alkenes with secondary amine nucleophiles
}

\author{
Dingqiao Yang*, Ping Hu, Yuhua Long, Yujuan Wu, Heping Zeng, Hui Wang
}

and Xiongjun Zuo

Open Access

\author{
Full Research Paper \\ Address: \\ School of Chemistry and Environment, South China Normal \\ University, Guangzhou 510006, People's Republic of China, Fax: \\ (+86)-20-39310187; Phone: (+86)-20-85210087 \\ Email: \\ Dingqiao Yang* - yangdq@scnu.edu.cn \\ * Corresponding author \\ Keywords: \\ chiral bisphosphine ligand; iridium catalyst; oxabicyclic alkenes; \\ ring-opening reaction
}

Beilstein Journal of Organic Chemistry 2009, 5, No. 53. doi:10.3762/bjoc.5.53

Received: 19 June 2009

Accepted: 24 July 2009

Published: 09 October 2009

Associate Editor: M. Rueping

(c) 2009 Yang et al; licensee Beilstein-Institut.

License and terms: see end of document.

\begin{abstract}
Iridium-catalyzed asymmetric ring-opening reactions of oxabicyclic alkenes with various aliphatic and aromatic secondary amines are reported for the first time. The reaction gave the corresponding trans-1,2-dihydronaphthalenol derivatives in good yields with moderate enantioselectivities in the presence of $2.5 \mathrm{~mol} \%[\operatorname{Ir}(\mathrm{COD}) \mathrm{Cl}]_{2}$ and $5 \mathrm{~mol} \%$ bisphosphine ligand $(S)$ - $p$-Tol-BINAP. The trans-configuration of $\mathbf{3} \mathbf{f}$ was confirmed by X-ray crystallography.
\end{abstract}

\section{Introduction}

Substituted dihydronaphthalenes are important molecules with different biological activities [1-5]. Therefore, the synthesis of these molecules has been an attractive research topic in recent years. Among the many reported methods for the preparation of the dihydronaphthalene skeleton, transition metal-catalyzed asymmetric ring-opening (ARO) of oxabicyclic alkenes is one of the most attractive because this reaction could potentially create two chiral centers in a single step.

Pioneering work in this field was first described by Caple et al. [6] and the group of Lautens [7-9]. In the past decades, the group of Lautens and others reported rhodium-catalyzed asymmetric ring-opening of oxabenzonorbornadiene with a wide range of nucleophiles including thiols [10], phenols [11], organoboronic acids [12,13], dialkylzincs [14,15], carboxylates [16], sulfur nucleophiles [17], and various amines [18,19].

In addition to rhodium catalysts, other transition metal catalysts may be used for asymmetric ring-opening reactions of oxabicyclic alkenes. These include complexes of copper [20-25], palladium [14,15,26-31], iron [32], and nickel [33-36]. Recently, we reported for the first time iridium-catalyzed asym- 
metric ring-opening of $N$-Boc-azabenzonorbornadiene with a wide range of secondary amines [37].

In this article, we will report ARO reactions of oxabicyclic alkenes with aliphatic and aromatic secondary amine nucleophiles using iridium-complex catalysts, which provide a fast and efficient access to chiral molecules with the dihydronaphthalene skeleton.

\section{Results and Discussion}

The ARO reaction involves many components of the chemical agents; we first attempted to optimize the ligand to iridium catalyst system (Scheme 1). In our initial experiments, we chose an achiral 1,1'-bis(diphenylphosphino)ferrocene (DPPF) ligand to validate the catalytic activity of the iridium complex. The product 2a was obtained in high yield (80\%) in the presence of $2.5 \mathrm{~mol} \%[\operatorname{Ir}(\mathrm{COD}) \mathrm{Cl}]_{2}$ and $5 \mathrm{~mol} \% \mathrm{DPPF}$ in THF after $5 \mathrm{~h}$.

Encouraged by this result, we then ran the asymmetric version of the same reaction using different kinds of chiral bisphosphine ligands as shown in Scheme 1. We first examined ferrocenyl bisphosphine ligand, $(R, S)$-PPF-P ${ }^{t} \mathrm{Bu}_{2}$, which was identified as the ligand giving the best reactivity and excellent enantioselectivity in Rh-catalyzed system [11-15]. Unfortunately, the desired ring-opened product $2 \mathbf{a}$ was obtained only in low yield $(47 \%)$ with reasonable enantioselectivity $(51 \%$ ee) in the iridium-catalyzed system. This suggested that $(R, S)$-PPF$\mathrm{P}^{t} \mathrm{Bu}_{2}$ was not an ideal ligand in iridium-catalyzed reactions, which prompted us to screen other ligands. Among the several chiral ligands we had tested, $(S)$-BINAP and $(S)$ - $p$-Tol-BINAP were found to give better yields and reasonable enantioselectivities. Moreover, in the case of $(S)$ - $p$-Tol-BINAP, the enantioselectivity is slightly higher than for $(S)$-BINAP $(52 \%$ ee vs $35 \%$ ee); therefore, we decided to use ( $S$ )- $p$-Tol-BINAP as the ligand for this ring-opening reaction.

Using ( $S$ )- $p$-Tol-BINAP as our standard ligand, we next investigated the effect of different solvents on reactivity and enantioselectivity (Table 1). Among the solvents examined for asymmetric ring-opening of oxabenzonorbornadiene 1a, THF was found to be the best in terms of yield and enantioselectivity (Table 1, entry 6). Reactions in toluene and dioxane afforded the desired product $2 \mathrm{a}$ in $70 \%$ and $76 \%$ yields, respectively. However, the enantioselectivities were slightly lower (Table 1, entries 3 and 4). On the other hand, temperature had a remarkable impact on reactivity and enantioselectivity. At room temperature, the reaction failed to give the corresponding ringopened product $2 \mathbf{a}$ (Table 1, entry 7). A sluggish reaction was observed at $65{ }^{\circ} \mathrm{C}$ (Table 1 , entry 8 ), whereas at a higher temperature, such as $100{ }^{\circ} \mathrm{C}$, the reaction gave a better yield and moderate enantioselectivity (Table 1 , entry 9 ).

Based on the above findings, we decided to use the following reaction condition as a standard to run the $\mathrm{ARO}$ reactions, which consisted of $2.5 \mathrm{~mol} \%[\operatorname{Ir}(\mathrm{COD}) \mathrm{Cl}]_{2}, 5 \mathrm{~mol} \%(S)-p$ Tol-BINAP, and 3.0 equiv of substituted $N$-alkylaniline in THF
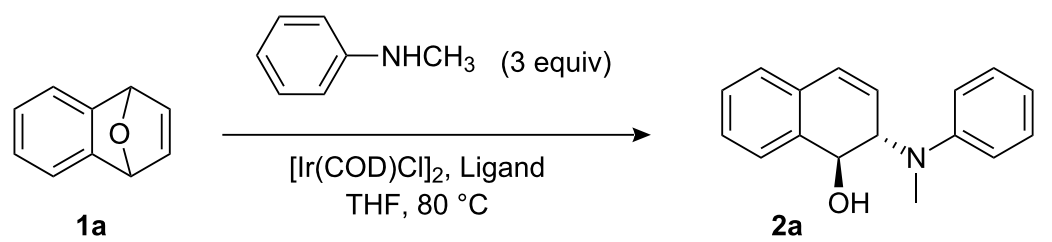

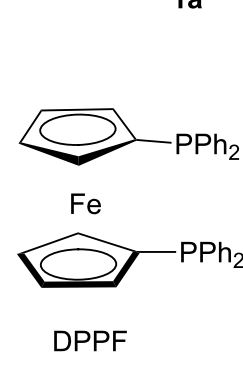

yield a: $80 \%$ after $5 \mathrm{~h}$

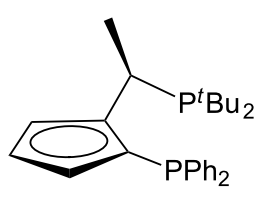

$\mathrm{Fe}$

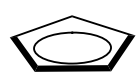

$(R, S)-P P F-P^{t} \mathrm{Bu}_{2}$

yield a. $47 \%$ after $24 \mathrm{~h}$ $51 \%$ ee $^{b}$<smiles>Pc1ccc2ccccc2c1-c1c(P)ccc2ccccc12</smiles>

(S)-BINAP

yield $^{\text {a. }} 75 \%$ after $12 \mathrm{~h}$ $35 \%$ ee $^{b}$

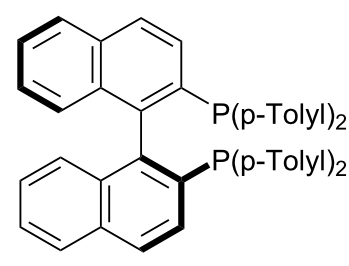

(S)-p-Tol-BINAP

yield a: $87 \%$

after $8 \mathrm{~h}$

$52 \%$ ee $^{b}$

a Isolated yield after silica gel column chromatography.

${ }^{b}$ Determined by HPLC with a Chiralcel AD column 
Table 1: Screening conditions for iridium-catalyzed asymmetric ring-opening of oxabenzonorbornadiene 1a with $N$-methylaniline. ${ }^{a}$

\begin{tabular}{|c|c|c|c|c|c|}
\hline Entry & Solvent & Temperature $\left({ }^{\circ} \mathrm{C}\right)$ & Time $(\mathrm{h})$ & Yield $(\%)^{b}$ & ee $(\%)^{c}$ \\
\hline 1 & DME & 100 & 12 & 48 & 16 \\
\hline 2 & $\mathrm{CH}_{3} \mathrm{CN}$ & 90 & 12 & 36 & 21 \\
\hline 3 & Toluene & 110 & 8 & 70 & 34 \\
\hline 4 & Dioxane & 110 & 8 & 76 & 46 \\
\hline 5 & THF & 100 & 12 & 65 & 50 \\
\hline 6 & THF & 80 & 8 & 87 & 52 \\
\hline 7 & THF & 25 & 48 & n.r. & - \\
\hline 8 & THF & 65 & 12 & 58 & 53 \\
\hline 9 & THF & 100 & 5 & 89 & 46 \\
\hline
\end{tabular}

aThe reaction was carried out with $1 \mathrm{a}(0.34 \mathrm{mmol})$ and 3.0 equiv of $\mathrm{N}$-methylaniline $(1.0 \mathrm{mmol})$ in a solvent $(2.0 \mathrm{~mL})$ in the presence of $[\mathrm{Ir}(\mathrm{COD}) \mathrm{Cl}]_{2}$ $(2.5 \mathrm{~mol} \%)$ and $(S)$ - $p$-Tol-BINAP $(5.0 \mathrm{~mol} \%)$. ' Isolated yields after silica gel column chromatography. ${ }^{\mathrm{C}}$ Determined by HPLC with a Chiralcel AD column.

Table 2: Scope of ring-opening of oxabenzonorbornadiene $1 \mathrm{a}$ with substituted $\mathrm{N}$-alkylaniline. ${ }^{\mathrm{a}}$<smiles>C1=CC2OC1c1ccccc12</smiles>

$1 \mathrm{a}$

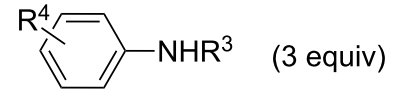

$[\operatorname{lr}(\mathrm{COD}) \mathrm{Cl}]_{2},(S)-p$-Tol-BINAP, $\mathrm{THF}, 80^{\circ} \mathrm{C}$

\begin{tabular}{lll} 
Entry & $\mathrm{R}^{3}$ & $\mathrm{R}^{4}$ \\
\hline
\end{tabular}

$1 \mathrm{CH}_{3} \quad \mathrm{H}$

2a-h

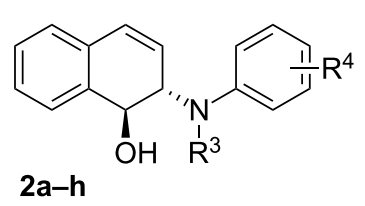

Product Time (h)

$\begin{array}{llll}\mathbf{2 a} & 8 & 87 & 52 \\ \mathbf{2 b} & 12 & 75 & 56 \\ \mathbf{2 c} & 24 & 48 & 74 \\ - & 60 & \text { n.r. } & - \\ - & 24 & \text { n.r. } & - \\ \mathbf{2 d} & 24 & 56 & 72 \\ \mathbf{2 e} & 12 & 70 & 55 \\ \mathbf{2 f} & 12 & 65 & 51 \\ \mathbf{2 g} & 12 & 71 & 65 \\ - & 60 & \text { n.r. } & - \\ \mathbf{2 h} & 6 & 85 & 50\end{array}$

aThe reaction was carried out with $1 \mathrm{a}(0.34 \mathrm{mmol})$ and 3.0 equiv of substituted $\mathrm{N}$-alkylaniline $(1.0 \mathrm{mmol})$ in $\mathrm{THF}(2.0 \mathrm{~mL})$ at $80{ }^{\circ} \mathrm{C}$ in the presence of

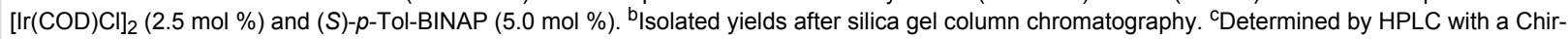
alcel AD column.

at $80{ }^{\circ} \mathrm{C}$. The results of the ARO of oxabenzonorbornadiene 1a are shown in Table 2.

The results demonstrated that the size of the alkyl group on nitrogen in the nucleophile significantly influenced the reactivity and enantioselectivity. For instance, in the reaction of 1a with $N$-methylaniline, which has a small group on $N$-atom, the ring-opening product $2 \mathrm{a}$ was obtained in $87 \%$ yield and $52 \%$ ee (Table 2, entry 1), whereas in the reaction of 1 a with $\mathrm{N}$-ethylaniline, which has a larger group on $\mathrm{N}$-atom, the yield decreased to $75 \%$, but the enantioselectivity was slightly increased (Table 2, entry 2). When $N$-allylaniline was used as a nucleophile, we obtained the product $2 \mathrm{c}$ in $48 \%$ yield with $74 \%$ ee (Table 2, entry 3 ). The reaction using $N$-cyclohexylaniline failed to give any ring-opened product because of the steric hindrance of the bulky group (Table 2, entry 4).

We then investigated the effect of substituent groups on the aromatic ring of $\mathrm{N}$-methylaniline. In 4-chloro- $N$-methylaniline, the reaction gave the desired product $2 \mathrm{e}$ in high yield with moderate enantioselectivity (Table 2 , entry 7 ). When 3 -chloro$\mathrm{N}$-methylaniline was used, the corresponding product 2d was obtained in slightly lower yield with slightly higher enantioselectivity (Table 2, entry 6). However, the reaction failed to 
give the expected product when ortho-substituted $\mathrm{N}$-methylanilines were used (Table 2, entry 5). Various parasubstituted $N$-methylanilines were shown to give the expected products in high yields with moderate enantioselectivities (Table 2, entries 8, 9 and 11). From Table 2, it was also found that the electronic property of the $N$-methylaniline had a significant impact on the reactivity. Electron-rich amines had higher reactivity than electron-deficient amines (Table 2, entries 1-3, 5, and 10).

To evaluate the scope of the reaction, we also examined various aliphatic secondary amines under optimized reaction conditions, and the results are summarized in Table 3. In most cases, aliphatic secondary amines reacted smoothly with $\mathbf{1 a}$ to give the corresponding ring-opened products ( $\mathbf{2} \mathbf{i}-\mathbf{l}$ ) in high yields (up to $90 \%$ ) with enantioselectivity ranging between $49 \%$ ee and $65 \%$ ee (Table 3, entries 5-8). We also found that the halide ions might play an important role in transition metal-catalyzed ARO reactions, in which the reactivity and enantioselectivity could be significantly improved by choosing a suitable halide ion. It was found that the reaction yields and enantioselectivities increased in the order of $\mathrm{F}<\mathrm{Cl}<\mathrm{Br}<$ I (Table 3, entries 2-5). But under the optimized reaction conditions, only a low yield (16\%) was obtained without halide ion additives (Table 3, entry 1). Therefore, simply changing the halide ligand on the iridium catalyst from chloride to iodide or bromide leads to improvements in the reactivity and enantioselectivity. On the other hand, the difference in enantioselectivity between the fluoro and the iodo complexes is particularly striking with piperidine as the nucleophile. With the Ir-F catalyst, $2 \mathbf{i}$ is formed in only $32 \%$ yield and $40 \%$ ee. Changing to the Ir-I complex gives $2 \mathbf{i}$ in $90 \%$ yield and $49 \%$ ee (Table 3, entries 2 and 5).

Having examined a wide range of secondary amines, it was found that the sterically hindered nucleophiles enhanced the enantioselectivities (up to $89 \%$ ee). Inspired by this observation, we then examined more sterically hindered substrate $\mathbf{1 b}$ or $\mathbf{1 c}$ in the presence of $2.5 \mathrm{~mol} \%[\operatorname{Ir}(\mathrm{COD}) \mathrm{Cl}]_{2}, 5 \mathrm{~mol} \%(S)-p$-TolBINAP, and 3.0 equiv of secondary amine nucleophiles in THF, at reflux. The results are summarized in Table 4 and Table 5 .

The reactions of substrate $\mathbf{1 b}$, which contained methoxy groups on the 5- and 8-positions, with various secondary amines provided ring-opened products $\mathbf{3 a}-\mathbf{j}$ in yields from $65 \%$ to $83 \%$ and enantioselectivities from $41 \%$ to $89 \%$. We further found

Table 3: ARO of oxabenzonorbornadiene 1a with various aliphatic secondary amines. ${ }^{\text {a }}$<smiles>C1=CC2OC1c1ccccc12</smiles>

$1 \mathbf{a}$

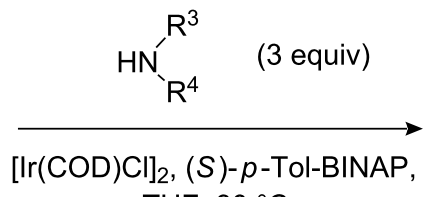
THF, $80^{\circ} \mathrm{C}$<smiles>[R]N([R])[C@H]1C=Cc2ccccc2[C@@H]1O</smiles>

2i-I

\begin{tabular}{lll} 
Entry & $\mathrm{HNR}^{3} \mathrm{R}^{4} \quad$ Additive $^{\mathrm{b}}$ \\
\hline
\end{tabular}

24

24

24

24

12

20

8

15
Yield $(\%)^{c} \quad$ ee $(\%)^{d}$

16

45

40

43

45

49

65

53

56

8<smiles>Clc1ccc(N2CCNCC2)cc1Cl</smiles>

$\mathrm{NH}_{4} \mathrm{I}$

2I

aThe reaction was carried out with $1 \mathrm{a}(0.34 \mathrm{mmol})$ and 3.0 equiv of aliphatic secondary amine $(1.0 \mathrm{mmol})$ in $\mathrm{THF}(2.0 \mathrm{~mL})$ at $80{ }^{\circ} \mathrm{C}$ in the presence of $\left[\operatorname{lr}(\mathrm{COD}) \mathrm{Cl}_{2}(2.5 \mathrm{~mol} \%)\right.$ and $(S)$-p-Tol-BINAP $(5.0 \mathrm{~mol} \%)$. ${ }^{\mathrm{b}}$ Additive is 1.0 equiv relative to $1 \mathrm{a}$. ' Isolated yields after silica gel column chromatography. dDetermined by HPLC with a Chiralcel AD column. 
Table 4: ARO of oxabenzonorbornadiene $1 \mathrm{~b}$ with various secondary amines. ${ }^{\text {a }}$<smiles>COc1ccc(OC)c2c1C1C=CC2O1</smiles>

$1 \mathrm{~b}$<smiles></smiles>

$\left[\operatorname{lr}(\mathrm{COD}) \mathrm{Cl}_{2},(S)-p\right.$-Tol-BINAP, $\mathrm{NH}_{4}$ l, THF, reflux

Entry $H N R^{3} R^{4}$<smiles>CNc1ccccc1</smiles>

2<smiles>CCNc1ccccc1</smiles><smiles>[R]N([R4])[C@H]1C=Cc2c(OC)ccc(OC)c2[C@@H]1O</smiles>

3a-j<smiles>CNc1cccc(C)c1</smiles>

4<smiles>CNc1ccc(F)cc1</smiles>

5<smiles>CNc1ccc(Cl)cc1</smiles>

6<smiles>CNc1ccc(Br)cc1</smiles>

7

8

9

10<smiles>C1CCNCC1</smiles><smiles>c1ccc2c(c1)CCNC2</smiles><smiles>c1ccc(N2CCNCC2)cc1</smiles><smiles>Clc1ccc(N2CCNCC2)cc1Cl</smiles>

$3 a$

roduct

Time (h)

12

81

76

$3 c$

8

68

aThe reaction was carried out with $\mathbf{1 b}(0.34 \mathrm{mmol})$ and 3.0 equiv of secondary amine $(1.0 \mathrm{mmol})$ in THF $(2.0 \mathrm{~mL})$ at reflux in the presence of $\left[\operatorname{Ir}(\mathrm{COD}) \mathrm{Cl}_{2}(2.5 \mathrm{~mol} \%)\right.$ and $(S)$ - $p$-Tol-BINAP $(5.0 \mathrm{~mol} \%)$. The $\mathrm{NH}_{4} \mathrm{l}$ additive is 1.0 equiv relative to $1 \mathrm{~b}$. blsolated yields after silica gel column chromatography. ${ }^{C}$ Determined by HPLC with a Chiralcel AD column.

that the substituent groups on the substrate did not apparently influence the yields, whereas the ee values increased, in some cases, to as high as $89 \%$ ee (Table 4 , entry 6).

The absolute configuration of ring-opened product $\mathbf{3 f}$ was demonstrated by X-ray crystallography. The single crystal was obtained by evaporation of the solvent from its solution in dichloromethane and petroleum ether. Its configuration was assigned as $(1 S, 2 S)$, and the hydroxyl group and 4-bromo- $N$ methylaniline group are in a trans relationship (Figure 1).

Based on our studies in this article, the reaction mechanism is proposed as shown in Scheme 2. The chiral dimeric iridium complex $\mathbf{A}$ is first formed. The dimer $\mathbf{A}$ is cleaved by solvation (THF) to become monomer $\mathbf{B}$. The oxygen atom and the double bond of oxabenzonorbornadiene 1a are then reversibly coordi- 
Table 5: Iridium-catalyzed asymmetric ring-opening reaction of substrate $1 c^{a}{ }^{a}$<smiles>COc1cc2c(cc1OC)C1C=CC2O1</smiles>

$1 c$

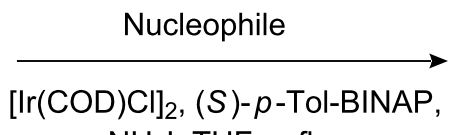

$\mathrm{NH}_{4} \mathrm{I}, \mathrm{THF}$, reflux

Entry Nucleophile Ligand<smiles>COc1cc2c(cc1OC)C(O)C(C#N)C=C2</smiles>

4a-e

(S)-p-Tol-BINAP

(S)-p-Tol-BINAP

(S)-p-Tol-BINAP

(S)-p-Tol-BINAP

(S)-p-Tol-BINAP
Product

Time (h)

Yield $(\%)^{b} \quad$ ee $(\%)^{c}$

$\begin{array}{llll}4 a & 24 & 70 & 37\end{array}$

$\begin{array}{llll}4 b & 24 & 68 & 49\end{array}$

$4 c-24$

73

4d

24

24

24

$4 \mathrm{e}$

62

27

38

59

16

1-(4-Methoxyphenyl)piperazine
3,4-Dichlorophenylpiperazine

aConditions: $\left[\mathrm{Ir}(\mathrm{COD}) \mathrm{Cl}_{2}(2.5 \mathrm{~mol} \%)\right.$ and ligand $(5.0 \mathrm{~mol} \%)$ were dissolved in THF and stirred for 10-20 min. Then $\mathrm{NH}_{4} \mathrm{l}$ was added and the mixture stirred for another 10-20 min. The substrate 1c was added and the mixture heated to reflux. The nucleophiles were added on the first sign of reflux. b/solated yields after silica gel column chromatography. 'Determined by HPLC with a Chiralcel AD column or AD column.

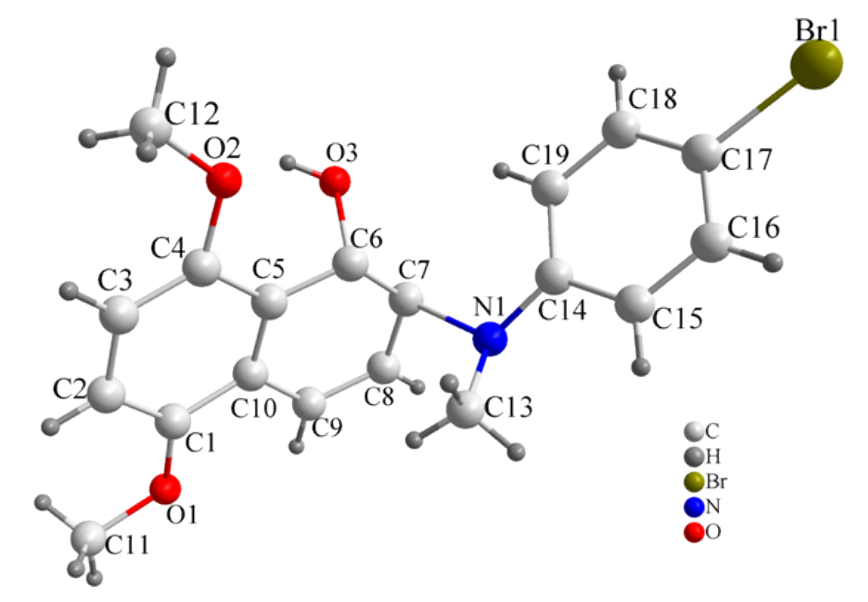

Figure 1: ORTEP plot for $\mathbf{3 f}$.

nated to the iridium center of the catalyst to give the intermediate $\mathbf{C}$. Oxidative insertion of $\mathbf{C}$ in to the $\mathrm{C}-\mathrm{O}$ bond forms $\mathbf{D}$. Then, attack of the secondary amine nucleophile along with configurational inversion is proposed to occur in an $\mathrm{S}_{\mathrm{N}} 2^{\prime}$ displacement of the iridium catalyst. The trans-1,2-dihydronaphthalenol product $\mathbf{2}$ is subsequently released and the iridium monomer $\mathbf{B}$ is regenerated.

\section{Conclusion}

In summary, we have explored the iridium-catalyzed ARO reaction of oxabicyclic alkenes with $N$-alkylated anilines or $\mathrm{N}$-substituted piperazine nucleophiles; the reactions gave the desired products in moderate to good yields with good enantioselectivities. The iridium-catalyzed ARO reactions described in this article featured lower cost compared with rhodium- catalyzed ARO reactions, which provided potential applications in asymmetric synthesis of chiral building blocks. The 1,2trans-configuration of the product was confirmed by X-ray crystallography. The search for an optimized ligand aiming to enhance enantioselectivity and the extension of this reaction to other types of substrates and nucleophiles are currently under investigation in our labs.

\section{Experimental}

General procedure (I) for the asymmetric ring-opening reactions of oxabenzonorbornadiene 1a with substituted $\mathrm{N}$-alkylaniline: A $5.0 \mathrm{~mL}$ round-bottom flask fitted with a reflux condenser was flame-dried under a stream of nitrogen and cooled to room temperature. $[\operatorname{Ir}(\mathrm{COD}) \mathrm{Cl}]_{2}(5.8 \mathrm{mg}$, $2.5 \mathrm{~mol} \%)$ and $(S)$-p-Tol-BINAP (10.7 mg, $5 \mathrm{~mol} \%)$ were 


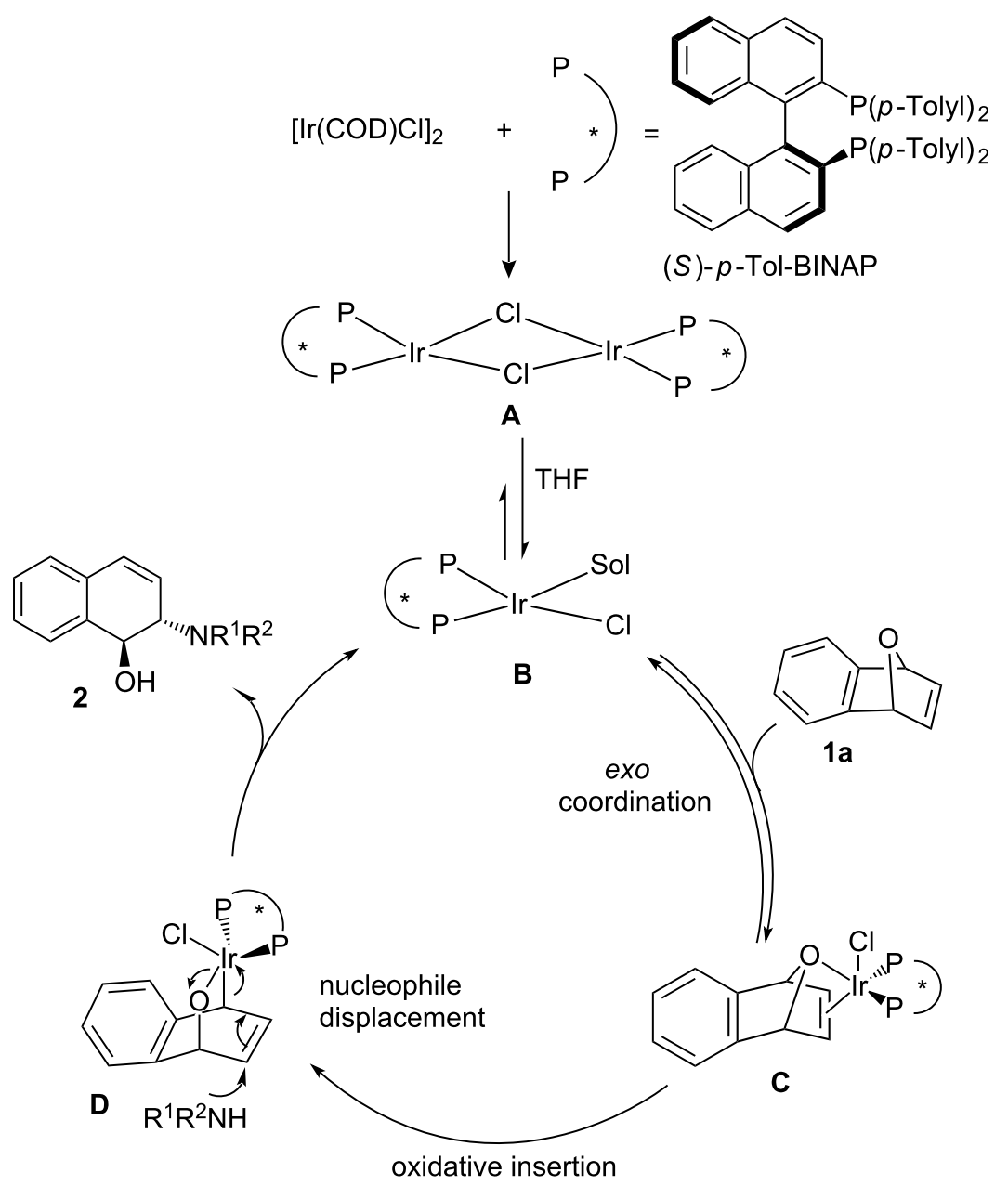

Scheme 2: Proposed mechanism for the ARO of oxabenzonorbornadiene 1a with secondary amine nucleophiles.

simultaneously added, followed by an addition of anhydrous tetrahydrofuran $(2.0 \mathrm{~mL})$. After they were stirred for about 10 min, oxabenzonorbornadiene 1a $(50.0 \mathrm{mg}, 0.347 \mathrm{mmol})$ was added and the resulting mixture was heated to reflux. On the first sign of reflux, nucleophile (3.0 equiv to 1a) was added. The temperature was continuously increased to $80{ }^{\circ} \mathrm{C}$ until the reaction was complete as determined by thin layer chromatography. The reaction mixture was then concentrated in vacuo and purified by column chromatography (silica gel: 200-300 mesh) to give the target product.

(1S,2S)-2-[Methyl(phenyl)amino]-1,2-dihydronaphthalen-1ol (2a): Following the general procedure (I), 2a was obtained as a colorless oil $(76.0 \mathrm{mg}, 87 \%) . R_{f}=0.17$ on silica gel (ethyl acetate:petroleum ether $=1: 20, \mathrm{v} / \mathrm{v})$. The ee was determined to be $52 \%$ using HPLC analysis on a Chiralcel AD column (hexane/2-propanol $=95 / 5,0.5 \mathrm{~mL} / \mathrm{min}, \lambda=254 \mathrm{~nm}$ ); Retention times were $32.9 \mathrm{~min}$ (major) and $36.5 \mathrm{~min}$ (minor). $[\alpha]_{\mathrm{D}}{ }^{20}$
+110.8 (c 1.00, $\mathrm{CHCl}_{3}$ ). IR (KBr, cm $\left.{ }^{-1}\right): 3514(\mathrm{~s}), 2980(\mathrm{~s})$, 2869(s), 1645(w), 1599(w), 1500(s), 1381(s), 1297(m), 1136(s), 934(m), 845(m), 794(m). ${ }^{1} \mathrm{H}$ NMR (400 MHz, $\left.\mathrm{CDCl}_{3}\right): \delta 7.54$ (d, $J=4.8 \mathrm{~Hz}, 1 \mathrm{H}), 7.28-7.23(\mathrm{~m}, 4 \mathrm{H}), 7.13-7.10(\mathrm{~m}, 1 \mathrm{H}), 6.96$ $(\mathrm{d}, J=8.4 \mathrm{~Hz}, 2 \mathrm{H}), 6.80(\mathrm{t}, J=7.2 \mathrm{~Hz}, 1 \mathrm{H}), 6.58(\mathrm{~d}, J=10.0$ $\mathrm{Hz}, 1 \mathrm{H}), 5.94-5.90(\mathrm{~m}, 1 \mathrm{H}), 5.10(\mathrm{~d}, J=9.6 \mathrm{~Hz}, 1 \mathrm{H}), 4.73(\mathrm{dd}$, $J=2.4,2.4 \mathrm{~Hz}, 1 \mathrm{H}), 2.84$ (d, $J=2.4 \mathrm{~Hz}, 3 \mathrm{H}), 2.38$ (br s, 1H). ${ }^{13} \mathrm{C}$ NMR $\left(100 \mathrm{MHz}, \mathrm{CDCl}_{3}\right): \delta 150.2,136.5,131.9,129.7$, 129.2, 128.1, 127.9, 127.7, 126.4, 125.6, 118.1, 114.7, 70.0, 63.5, 33.4. MS (ESI) $m / z$ Calcd for $\mathrm{C}_{17} \mathrm{H}_{17} \mathrm{NO}\left(\mathrm{M}^{+}\right)$: 251.13; Found: 251.83. Anal. Calcd for $\mathrm{C}_{17} \mathrm{H}_{17} \mathrm{NO}$ : C, 81.24; H, 6.82; N, 5.57. Found: C, 81.52; H, 6.92; N, 5.73.

See Supporting Information for details of the syntheses of the new compounds $\mathbf{2} \mathbf{b}-\mathbf{I}, \mathbf{3 a - j}$, and $\mathbf{4 a - d}$. 


\section{Supporting Information}

Experimental procedures and full characterization data for all the new compounds including optical rotations, IR, ${ }^{1} \mathrm{H}$ NMR and ${ }^{13} \mathrm{C}$ NMR, MS and elemental analysis are provided in the Supporting Information. In addition, X-ray structure data for compound $\mathbf{3 f}$ are given.

\section{Supporting Information File 1}

Experimental and analytical data

[http://beilstein-journals.org/bjoc/content/supplementary/

1860-5397-5-53-S1.doc]

\section{Acknowledgments}

We are grateful to the National Natural Science Foundation of China (No. 20772036) and the Natural Science Foundation of Guangdong Province (No. 8251063101000002 and No. $7005804)$ for the financial support.

\section{References}

1. Johnson, B. M.; Chang, P. T. L. Analytical Profiles of Drug Substances and Excipients; 1996; Vol. 24, p 443.

(For reviews.)

2. Snyder, S. E.; Aviles-Garay, F. A.; Chakraborti, R.; Nichols, D. E.; Watts, V. J.; Mailman, R. B. J. Med. Chem. 1995, 38, 2395-2409. doi:10.1021/jm00013a015

3. Kamal, A.; Gayatri, L. Tetrahedron Lett. 1996, 37, 3359-3362. doi:10.1016/0040-4039(96)00546-1

4. Kim, K.; Guo, Y.; Sulikowski, G. A. J. Org. Chem. 1995, 60, 6866-6871. doi:10.1021/jo00126a043

5. Perrone, R.; Berardi, F.; Colabufo, N. A.; Leopoldo, M.; Tortorella, V.; Fiorentini, F.; Olgiati, V.; Ghiglieri, A.; Govoni, S. J. Med. Chem. 1995, 38, 942-949. doi:10.1021/jm00006a013

6. Caple, R.; Chen, G. M. S.; Nelson, J. D. J. Org. Chem. 1971, 36, 2874-2876. doi:10.1021/jo00818a032

7. Lautens, M. Synlett 1993, 177-185. doi:10.1055/s-1993-22393

8. Lautens, M.; Colucci, J. T.; Hiebert, S.; Smith, N. D.; Bouchain, G. Org. Lett. 2002, 4, 1879-1882. doi:10.1021/ol025872f

9. Lautens, M.; Fagnou, K.; Hiebert, S. Acc. Chem. Res. 2003, 36, 48-58. doi:10.1021/ar010112a

10. Bates, C. G.; Gujadhur, R. K.; Venkataraman, D. Org. Lett. 2002, 4, 2803-2806. doi:10.1021/ol0264105

11. Lautens, M.; Fagnou, K.; Taylor, M. Org. Lett. 2000, 2, 1677-1679. doi:10.1021/ol005729r

12. Lautens, M.; Dockendorff, C.; Fagnou, K.; Malicki, A. Org. Lett. 2002, 4, 1311-1314. doi:10.1021/ol0256062

13. Murakami, M.; Igawa, H. Chem. Commun. 2002, 390-391. doi:10.1039/b108808d

14. Lautens, M.; Hiebert, S.; Renaud, J.-L. Org. Lett. 2000, 2, 1971-1973. doi:10.1021/ol006052a

15. Lautens, M.; Renaud, J.-L.; Hiebert, S. J. Am. Chem. Soc. 2000, 122, 1804-1805. doi:10.1021/ja993427i

16. Lautens, M.; Fagnou, K. Tetrahedron 2001, 57, 5067-5072. doi:10.1016/S0040-4020(01)00351-9
17. Leong, P.; Lautens, M. J. Org. Chem. 2004, 69, 2194-2196. doi:10.1021/jo035730e

18. Lautens, M.; Fagnou, K.; Yang, D.-Q. J. Am. Chem. Soc. 2003, 125, 14884-14892. doi:10.1021/ja034845x

19. Webster, R.; Böing, C.; Lautens, M. J. Am. Chem. Soc. 2009, 131, 444-445. doi:10.1021/ja807942m

20. López, F.; Harutyunyan, S. R.; Minnaard, A. J.; Feringa, B. L. J. Am. Chem. Soc. 2004, 126, 12784-12785. doi:10.1021/ja046632t

21. López, F.; van Zijl, A. W.; Minnaard, A. J.; Feringa, B. L. Chem. Commun. 2006, 409-411. doi:10.1039/b513887f

22. Tissot-Croset, K.; Polet, D.; Alexakis, A. Angew. Chem., Int. Ed. 2004, 43, 2426-2428. doi:10.1002/anie.200353744

23. Falciola, C. A.; Tissot-Croset, K.; Alexakis, A. Angew. Chem., Int. Ed. 2006, 45, 5995-5998. doi:10.1002/anie.200601855

24. Arrayás, R. G.; Cabrera, S.; Carretero, J. C. Org. Lett. 2003, 5, 1333-1336. doi:10.1021/ol034283m

25. Bertozzi, F.; Pineschi, M.; Macchia, F.; Arnold, L. A.; Minnaard, A. J.; Feringa, B. L. Org. Lett. 2002, 4, 2703-2705. doi:10.1021/ol026220u

26. Lautens, M.; Dockendorff, C. Org. Lett. 2003, 5, 3695-3698. doi:10.1021/ol035369i

27. Li, M.; Yan, X.-X.; Hong, W.; Zhu, X.-Z.; Cao, B.-X.; Sun, J.; Hou, X.-L. Org. Lett. 2004, 6, 2833-2835. doi:10.1021/ol048816i

28. Zhang, T.-K.; Mo, D.-L.; Dai, L.-X.; Hou, X.-L. Org. Lett. 2008, 10, 3689-3692. doi:10.1021/ol801294b

29. Cabrera, S.; Arrayás, R. G.; Carretero, J. C. Angew. Chem. 2004, 116, 4034-4037. doi:10.1002/ange.200460087

30. Chen, C.-L.; Martin, S. F. Org. Lett. 2004, 6, 3581-3584. doi:10.1021/ol048517t

31. Imamoto, T.; Saitoh, Y.; Koide, A.; Ogura, T.; Yoshida, K. Angew. Chem. 2007, 119, 8790-8793. doi:10.1002/ange.200702513

32. Nakamura, M.; Matsuo, K.; Inoue, T.; Nakamura, E. Org. Lett. 2003, 5 , 1373-1375. doi:10.1021/ol034375b

33. Lautens, M.; Chiu, P.; Ma, S.; Rovis, T. J. Am. Chem. Soc. 1995, 117, 532-533. doi:10.1021/ja00106a062

34. Lautens, M.; Ma, S. J. Org. Chem. 1996, 61, 7246-7247. doi:10.1021/jo961615a

35. Lautens, M.; Rovis, T. J. Org. Chem. 1997, 62, 5246-5247. doi:10.1021/jo971115x

36. Rayabarapu, D. K.; Cheng, C.-H. Chem.-Eur. J. 2003, 9, 3164-3169. doi:10.1002/chem.200204506

37. Yang, D.-Q.; Long, Y.-H.; Wang, H.; Zhang, Z.-M. Org. Lett. 2008, 10, 4723-4726. doi:10.1021/ol801768e 


\section{License and Terms}

This is an Open Access article under the terms of the Creative Commons Attribution License

(http://creativecommons.org/licenses/by/2.0), which permits unrestricted use, distribution, and reproduction in any medium, provided the original work is properly cited.

The license is subject to the Beilstein Journal of Organic Chemistry terms and conditions:

(http://www.beilstein-journals.org/bjoc)

The definitive version of this article is the electronic one which can be found at:

doi:10.3762/bjoc.5.53 